\title{
Museum Presentation
}

\author{
DOLÁK, Jan a ŠOBÁŇOVÁ, Petra. Museum Presentation. Olomouc: \\ Univerzita Palackého v Olomouci, 2018. 378 s. ISBN 978-80-244-5522-8.
}

sbírky jakožto pamětové nosiče procházejí tezaurační fází, jsou dále ukotveny právě v muzejní prezentaci, kde autoři navazují s popisem vývoje jejího charakteru až do současného rozvíjení user-friendly přístupů. V krátkosti jsou shrnuty též základní pojmy - expozice, výstava, komunikace, veřejnost, veřejné mínění. Autoři se zde logicky věnují terminologickým nejasnostem slov display, exhibit a exhibition.

V další sekci jsou rozebrány základní části teoretického pojímání muzejní prezentace - prezentace a reprezentace informací, související pojem ostenze, komunikační kanál, ontická autenticita, feedback. Srozumitelně je popsána efektivita a funkce komunikace, což pomáhá k celkovému pochopení jejího smyslu a významu. Muzejní komunikace není založena jen na kontextuálním předávání informací, upozorňováno je i na (většinou) kontinuální a konzistentní formu, stejně jako pochopení veřejnosti. Nezůstává jen u zdůraznění vzdělávací, výchovné a poznávací podoby přístupů $\mathrm{k}$ prezentaci - důraz je kladen i na socializační a společensky integrující rozměr, oblast, které jsou věnovány i další vybrané části textu.

Muzejní expozice je pojímána jako specifický "druh textu“, čtený v rámci hermeneutického kruhu, umožňujícího reinterpretace. $K$ těm dochází at již vlivem dobového kontextu, tak např. i úmysly původců, rozdílnými způsoby uvažování, závislostí na proměnlivém chápání světa. Návštěvník muzea je účastníkem oboustranného komunikačního procesu (participant to a two-way communication process), zároveň je i př́mým vykonavatelem interpretačního aktu (executor of interpretation).

Ačkoli bylo muzeum v minulosti chápáno primárně jako vědecká instituce, stále jasněji vystupuje do popředí i jeho edukační rozměr, muzejní expozice coby edukační
Václav Rutar

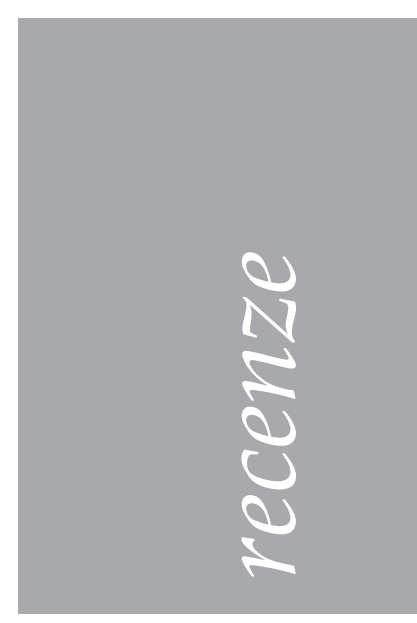

Mgr. Václav Rutar Národní technické muzeum vaclav.rutar@ntm.cz 
médium, naplňující pedagogickou zásadu názornosti (rule of being illustrative). Autentické sbírkové předměty mají potenciál překonávat verbalismus školního vzdělávání. Autoři dále pojí v obecnější rovině muzejní prezentaci $\mathrm{s}$ enkulturací a muzeum popisují spíše jako nositele sociální informace (bearer of social information), součást informační paměti (part of information memory). Výše zmíněné procesy tak výrazně přispívají ke kulturní kontinuitě.

V tretí kapitole je široce rozebráno chápání muzejního předmětu a jeho přeměna $\mathrm{v}$ roli exponátu. Muzejní předmět je chápán jako dokument, znak a informace. Charakter "metareality" exponovaného sbírkového předmětu je spojován s pojetím reality "object-vehiculum-interpretans" u Edwiny Taborsky, nepř́mým odkazem ke komunikačnímu kanálu a jeho nazírání z muzeologických hledisek. Jak autoři poukazují, muzejní prezentací není představena neměnná pravda (constant truth) jedná se de facto o pokus o vizualizaci panujícího diskurzu (attempt to visualise existing discourse). Představovány pak nejsou přednostně předměty, ale určité téma, "the concept behind an exhibition".

Dalším tématem této části je obecné pojednání o typech expozičních prvků není opomenuto známé dělení předmětů na naturfakty, artefakty a mentefakty s důrazem na pojem muzeálie jakožto originálního svědka - autentického reprezentanta - transformované muzealizací do role svědka kulturních obsahů (cultural contents). Výrazně je pojednána problematika substitutů a alternativní prezentace sbírek. U substitutů autoři využívají starší dělení Vladimíra Tkáče (přebírané Friedrichem Waidacherem), zpracovávají však i jejich formu didaktičnosti, zaměření na digitalizaci a technickou povahu. Logicky jsou tedy dále zmíněna science centra a nová média, která doplňují současnou muzejní prezentaci (smartphones, $Q R$ codes, videomapping, virtual museums).

Následující část knihy je věnována muzejnímu výstavnímu jazyku, který je „encoded in the language of things". Pozastavuji-li se autoři dále s odkazem na Martina R.
Schärera nad různými druhy tohoto jazyka (estetický, divadelní, didaktický, asociativní), domnívám se, že by v tomto př́ípadě šlo spíše o mluvu (parole) než jazyk - to by mohlo být výrazněji rozlišeno. V textu je na tuto otázku nahlíženo z jiného pohledu - výstavní jazyk (parole?) zde není chápán jako próza, ale spíše staccato text, esej či fragmentární poezie.

Velký prostor je následně věnován klasifikaci expozic a jejich vazbám na odlišné skupiny návštěvníků. Expozice jsou v textu děleny klasicky na trvalé, dočasné (výstavy), marginální a studijní. Významnější je ale jejich rozdělení z hlediska dvojího možného př́stupu - kontextuálního a narativního. Zatímco v prrípadě kontextuálně pojednaných expozic je poukázáno zejména na souvislosti a původní společenské vazby, narativní expozice již v označení s sebou nese př́běh a chronologičnost, je promluvou (discourse). Váže se tak blíže na představivost návštěvníků, nepředkládá pouze jasná fakta. Narativnost je mj. svázána i s využitím orální historie, která je při tvorbě expozic tohoto typu výraznou pomůckou.

V nejobecnější rovině přístupu k návštěvníkům jsou muzea dělena na museum contemplativum a museum activum. Zatímco kontemplativní prístup $\mathrm{k}$ prezentaci předpokládá již znalost a poučenost (jde o jakési introvertní představené sbírky, adorované mlčící exponáty), museum activum přináší očekávané možnosti komunikace pro dříve prímo nekonkretizované návštěvnické skupiny - rodiny s dětmi, školní skupiny, handicapované. Poznávání tak může být u dětí vázáno na hry a práci s didaktickými exponáty - pojednán je též i význam a potřeba dětských muzeí a center. U handicapovaných návštěvníků nabývá důležitosti zohlednění bezbariérových př́stupů, dotykových objektů, zvukových záznamů ad. Samozřejmostí je dnes pojímání muzeí (a tedy ve vazbě $\mathrm{k}$ návštěvníkům především muzejních expozic a výstav) jako "visitor-friendly" institucí. Autoři vyjmenovávají množství dnes obvykle uváděných očekávání návštěvníků, které je třeba plnit - snadnou orientaci, pohodlí, vřelé 
přijetí, sociální interakci, možnost volby a vlastní kontrolu na návštěvou. To je jistě vše $\mathrm{v}$ pořádku, ale je uváděn i možný vznikající problém - muzea mohou začít produkovat expozice, které nebudou ale mít ani částečně vědeckou či intelektuální formu a budou se snažit pouze pritahovat návštěvníky. Dovoluji si citovat autory uváděnou větu Josie Appleton, shrnující uvedené: "museums love the public so much, that they have strayed from the very reasons for which they were established".

Zpracována je též problematika architektonického řešení prostoru souvisejícího $\mathrm{s}$ prezentací. Autoři se věnují $\mathrm{v}$ této věci jasně daným okruhům - osvětlení, teplotě, př́stupu, posezení, občerstvení, čistotě nebo pocitům bezpečnosti, a to mnohdy s odkazem na vybrané expozice. Do širšího pojetí je brána prímo i muzejní stavba, která může sama být "řečí muzea" (the language of building becomes the language of museum). Zde považuji za zbytečnou přílišnou konkretizaci - jsou pojednány architektonické postupy především ve stavbách Zahy Hadid a Daniela Libeskinda. Dle mého soudu by mělo větší smysl zůstat $\mathrm{u}$ hlubšího výkladu v obecné rovině a $\mathrm{v}$ prrípadě potřeby odkazovat $\mathrm{k}$ širšímu okruhu architektů.

$\mathrm{V}$ šesté kapitole se autoři věnují muzejní výstavní tvorbě, pojednání otázek souvisejících s přípravou muzejních výstav a expozic. Rozdělují ji na několik fází, které se vážou na připravenou partituru, vznikající (alespoň teoreticky) klasickým způsobem námět - libreto - scénáŕ. Do otevření výstavy/expozice jsou vyloženy fáze koncepční, vývojová a produkční, po zpřístupnění pak funkční a vyhodnocovací (assessment phase). Problematika muzejní evaluace zde bohužel není pojednána více, ač je zmíněna jako neprávem opomíjená fáze a uváděna jako př́padný odrazový můstek pro další výstavy (springboard to other exhibitions). To je jistě škoda, především otázka předběžné a formativní evaluace by první tři fáze dobře doplnila. Do skupiny podílející se na tvorbě výstav je řazen muzeolog, pedagog, architekt, grafik, výtvarník a instalační pracovníci. Role pedagoga je zde již rozebraná konkrétněji, ačkoli je jí plně věnována až následující kapitola. Práce pedagoga je mnohdy podceňována $\mathrm{v}$ porovnání s prací odborníků prezentovaných oborů. Zatímco oborový specialista studuje dostupné materiály, aby mohl produkovat další obsah, pedagog poznává obsah proto, aby jej mohl predat a objasnit lidem, dochází $\mathrm{k}$ didaktické transformaci. Toto malé vysvětlení považuji za důležité spojení muzeologie a muzejní pedagogiky, i když autoři tuto spojitost př́mo nezmiňuií. Jedná se o další z typů transformací, s kterými je muzejní teorie a praxe spjata prvním je jistě muzealizační činností prováděný přechod selektovaných předmětů do kulturní metaskutečnosti.

$\mathrm{V}$ závěrečné, sedmé kapitole jsou pojednána vybraná doporučení. Podrobně je popsána úloha muzejního pedagoga, resp. možnost pedagogického vyznění prezentace. Vyjmenovány jsou hlavní zásady - přiměřenost, komplexnost, emocionálnost a názornost. Úkolem muzea je podpořit interakci návštěvníků $\mathrm{s}$ exponáty, umožnit aktivní participaci, muzeum by nemělo být knihou, kterou čteme ve stoje - „a museum exhibition is not a library and so it should not to be a book that we read standing". Toto pojetí autoři ještě potvrzují rozborem využívání textů $\mathrm{v}$ muzejní prezentaci.

Publikace o muzejní prezentaci je uzavřena uvedením problematických momentů současné prezentace. Zmíněna je zejména snaha říci vše (attempting to say all), strach $\mathrm{z}$ marginality tématu (fear from marginality) a s tím související snaha o světovost (attempt to gain a worldwide reputation) a časté chyby v pojetí textů (mistakes in the concept of texts). S despektem je nahlédnuto i na snahu o vyváženost a s rozvíjející se technikou i odklon od reality (fake-lore). Řešením shledávají autoři tvorbu širších a kvalitnějších programů pro pracovníky muzeí, širokou dostupnost a produkci muzejní literatury, vypracování muzejní kritiky a především hlubší analýzu působnosti expozic na různé skupiny návštěvníků.

Publikace Museum Presentation je komplexně zpracovanou problematikou jedné 
části muzejní práce, a to jak z pozic muzeologických, tak muzeografických. Autoři se věnují všem důležitým částem - historickému vývoji prezentace nejen muzejního charakteru, pojetí muzejního exponátu $\mathrm{v}$ teoretické rovině, inovativním prístupům $\mathrm{v}$ souvislosti s novými médii, interaktivitou. Velký důraz je kladen na výklad potřeb různých typů návštěvníků. Opomenut $\mathrm{v}$ této souvislosti nezůstává ani výklad práce muzeí s dětskými skupinami a handicapovanými. Prostory prezentací jsou popisovány i na základě přístupư z oblasti muzejní architektury. Knihu lze tak doporučit nejen studentům oboru muzeologie a př́padných dalších, směřovaných do oblastí kultury, ale i všem muzejním pracovníkům, kterých se při jejich práci uvedená témata týkají. 